\title{
Cerebral abscess in the under 6 month age group
}

\author{
D L SUTTON AND R A OUVRIER \\ Department of Neurology, Royal Alexandra Hospital for Children, Camperdown, Australia
}

SUMMARY Cerebral abscess is rare in children under 6 months of age but is associated with high mortality and morbidity. We report the 12 cases admitted to this hospital in the past 20 years and review the published reports on cerebral abscess in infancy and childhood. Although mortality associated with cerebral abscess in infancy has improved, morbidity is still high. We recommend that all infants aged under 6 months presenting with bacterial meningitis have a computed tomogram or ultrasound examination to exclude cerebral abscess and hydrocephalus.

\section{Patients}

The study included all infants aged less than 6 months admitted with cerebral abscess in the years 1961-82, except those with any predisposing congenital anomaly such as meningomyelocoele.

\section{Results}

Clinical details of the infants are listed in Table 1. Eleven of the babies were 3 months of age or less.
Three were preterm. Two preterm babies and one other had a documented preceding septicaemia. Seven infants presented with fits (6 generalised, one focal), 9 with fever, 8 with meningitis, and 7 with raised intracranial pressure, evidenced by a bulging fontanelle or abnormally increasing head circumference. Only one had a focal neurological sign (a divergent strabismus).

The method of diagnosis of cerebral abscess varied according to the technology available. Of the three patients early in the series (1961-2) one

Table 1 Clinical features of infants with cerebral abscess

\begin{tabular}{|c|c|c|c|c|}
\hline Case (year) & Sex & Age & Predisposing conditions and symptoms & Signs \\
\hline $1(1961)$ & $\mathbf{M}$ & 10 dys & Preterm, 35 wks: fitting $<24$ hrs. & Fever, no focal signs. \\
\hline $2(1961)$ & $\mathbf{M}$ & 5 mths & Fever, irritability, poor feeding for 7 dys. & No focal signs, fever. \\
\hline $3(1962)$ & $\mathbf{F}$ & 3 wks & Fitting $<24$ hrs. & $\begin{array}{l}\text { Divergent squint, rapid rise in head } \\
\text { circumference (OFC). }\end{array}$ \\
\hline $4(1969)^{*}$ & $\mathbf{M}$ & 6 wks & $\begin{array}{l}\text { Preterm, } 32 \text { wks: severe HMD, apnoea, anaemia, } \\
\text { proteus and streptococcus septicaemia wk } 1 \text { of life. }\end{array}$ & $\begin{array}{l}\text { Rapid increase in OFC over } \\
1 \text { wk before transfer. }\end{array}$ \\
\hline 5 (1972) & $\mathbf{M}$ & 5 wks & Febrile, irritable, drowsy for 3 dys. & Full fontanelle, OFC $>97$ th percentile. \\
\hline $6(1972)$ & $\mathbf{F}$ & 6 wks & Febrile, fitting for 1 wk. & Febrile, head and eyes deviated to right. \\
\hline 7 (1978)* & $\mathbf{M}$ & 6 wks & Fitting, lethargic for 3 dys. & Rapidly increasing OFC. \\
\hline 8 (1978)* & $\mathbf{M}$ & 6 wks & Fitting and vomiting for 3 dys. & Fever, hypertonia, meningism. \\
\hline $9(1981)^{*}$ & $\mathbf{F}$ & 3 mths & $\begin{array}{l}\text { Preterm, } 28 \text { wks: severe HMD, serratia sepsis in } \\
\text { neonatal period, fever. }\end{array}$ & Febrile, full fontanelle 6 dys before diagnosis. \\
\hline $10(1982)^{*}$ & $\mathbf{M}$ & 4 wks & $\begin{array}{l}\text { Small for gestational age term infant: } \\
\text { proteus meningitis at } 3 \text { wks. }\end{array}$ & Fitting, febrile, full fontanelle. \\
\hline $11(1982)^{*}$ & $\mathbf{M}$ & 5 wks & $\begin{array}{l}\text { Suppurative bilateral otitis media, } \\
\text { proteus meningitis at } 4 \text { wks. }\end{array}$ & $\begin{array}{l}\text { Fever, irritable, full fontanelle, head to right, } \\
\text { eyes to left: ultrasound suggested abscess. }\end{array}$ \\
\hline $12(1982)^{*}$ & $\mathbf{F}$ & 6 wks & $\begin{array}{l}\text { Citrobacter septicaemia on dy } 3 \text {, citrobacter } \\
\text { meningitis at } 3 \text { wks. }\end{array}$ & Fever, fitting, full fontanelle, hyper-reflexia. \\
\hline
\end{tabular}




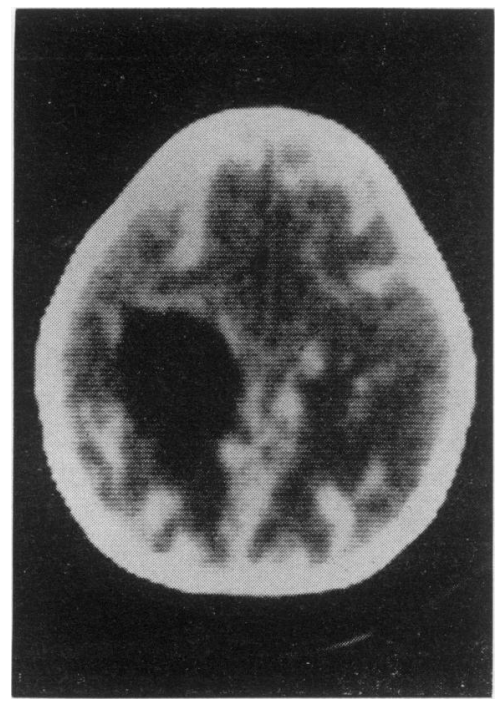

Fig. 1 CT scan case 10 showing abscess and cerebritis.

was diagnosed at necropsy, one by ventricular and cerebral puncture, and one by ventriculogram (Table 2). The three infants presenting between 1969 and 1972 were diagnosed by radionuclide (RN) scans and computed tomography (CT) was available for the 6 most recent cases (1978-82). Five of these 9 infants had multiple abscesses. A clinical diagnosis of cerebral abscess was suspected in only two infants.

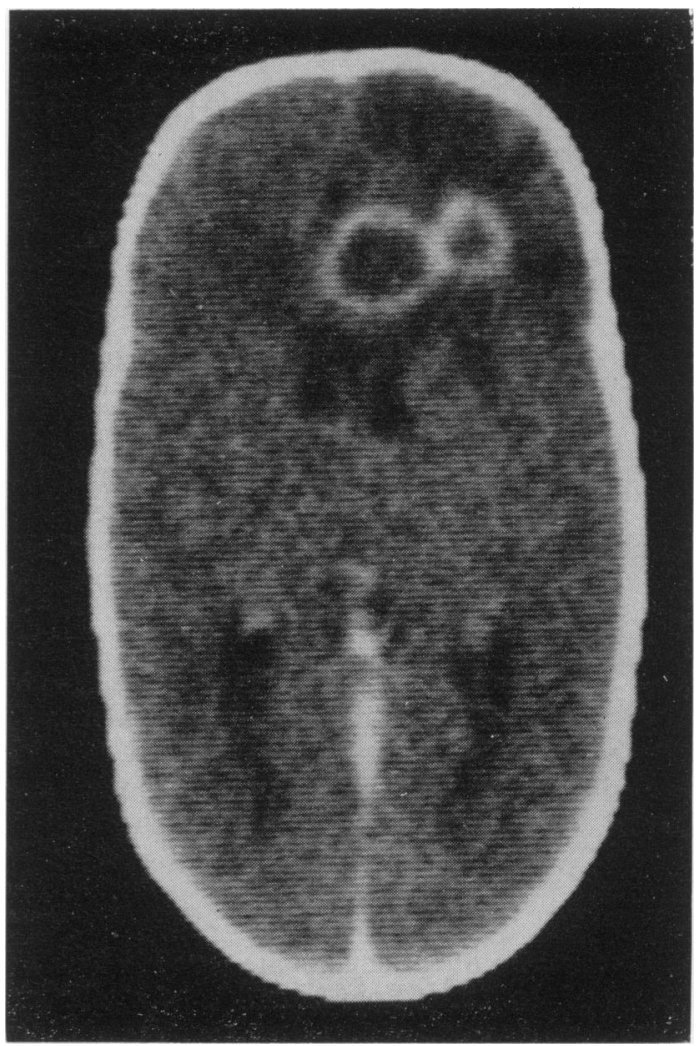

Fig. 2 CT scan case 9 showing frontal abscess.

Table 2 Mode of diagnosis, EEG result, and site of abscess

\begin{tabular}{|c|c|c|}
\hline Case (year) & Mode of diagnosis. EEG findings & Site of abscess \\
\hline $1(1961)$ & Necropsy: no EEG. & Frontal and occipital $-\mathbf{R}$ and $\mathbf{L}$. \\
\hline $2(1961)$ & Ventricular and cerebral punctures on dy of admission: no EEG. & R parietal. \\
\hline $3(1962)$ & Ventriculogram 3 wks after admission: EEG, frontotemporal abnormality. & L parietal. \\
\hline $4(1969)$ & $\begin{array}{l}\text { Ventriculogram, nuclear brain scan dy of admission: } \\
\text { EEG, low voltage, no focal anomaly. }\end{array}$ & $\mathbf{R}$ frontal, $\mathbf{L}$ temperofrontal. \\
\hline $5(1972)$ & Nuclear brain scan 7 dys after admission: EEG, $R$ frontal slow wave focus. & $\mathbf{R}$ frontal, $\mathbf{L}$ posterior parietal. \\
\hline $6(1972)$ & Nuclear brain scan 5 dys after admission: no EEG. & $\mathbf{L}$ posterior, $\mathbf{R}$ parietal. \\
\hline $7(1978)$ & $\begin{array}{l}\text { Nuclear brain scan and CT scans on dy of admission: EEG, } \\
\text { multifocal epileptic process. }\end{array}$ & $\mathbf{L}$ and $\mathbf{R}$ frontal and occipital. \\
\hline $8(1978)$ & CT scan dy of admission: EEG, multifocal bilateral epileptic activity. & $\mathbf{R}$ frontal. \\
\hline $9(1981)$ & CT scan 3 dys after admission: no EEG. & Large $\mathbf{L}$ and midline frontal. \\
\hline $10(1982)$ & $\begin{array}{l}\text { Ultrasound, CT scans done serially before and during abscess formation. } \\
\text { EEG, scattered epileptic activity and abnormal bilateral low } \\
\text { voltage activity. }\end{array}$ & Roof of $\mathbf{R}$ lateral ventricle. \\
\hline $11(1982)$ & Ultrasound, CT scan dy of admission: no EEG. & Bilateral frontal. \\
\hline $12(1982)$ & $\begin{array}{l}\text { CT scan dy of admission RAHC (6 dys after onset of fever, } \\
\text { irritability), no EEG. }\end{array}$ & R frontal. \\
\hline
\end{tabular}

$\mathbf{R}=$ right $\mathbf{L}=$ left $; \mathbf{E E G}=$ electroencephalogram; $\mathbf{C T}=$ computed tomography. 
Table 3 Laboratory findings in infants with cerebral abscess

\begin{tabular}{|c|c|}
\hline Case (year) & Laboratory findings \\
\hline $1(1961)$ & $\begin{array}{l}\text { Lumbar CSF-polymorphs } 1 \times 109 / 1 \text {; protein } 4 \mathrm{~g} / 1 \text {; Gram negative rods; coliform bacillus. } \\
\text { Culture of abscess contents-Escherichia coli. }\end{array}$ \\
\hline $2(1961)$ & $\begin{array}{l}\text { Haemoglobin } 12.6 \mathrm{~g} / \mathrm{dl} \text {; white cell count } 26 \times 109 / 1 \text { (mostly neutrophils) Culture of abscess contents-Staphylococcus } \\
\text { aureus. }\end{array}$ \\
\hline $3(1962)$ & $\begin{array}{l}\text { Lumbar CSF-polymorphs } 4.5 \times 109 / 1 \text {; protein } 6 \mathrm{~g} / 1 \text {; culture, } E \text {. coli. Culture of abscess contents-E. coli. } \\
\text { Haemoglobin } 16.6 \mathrm{gl} \mathrm{dl} \text {; white cell count } 30 \times 10 \% / 1(65 \% \text { polymorphs }) .\end{array}$ \\
\hline $4(1969)$ & $\begin{array}{l}\text { Blood culture-Proteus vulgaris. Haemoglobin } 11.8 \mathrm{~g} / \mathrm{dl} \text {; white cell count, normal total count with left shift. } \\
\text { Ventricular tap culture-Pr. vulgaris. Culture of abscess contents-Pr. vulgaris. }\end{array}$ \\
\hline 5 (1972) & $\begin{array}{l}\text { Haemoglobin } 11 \mathrm{~g} / \mathrm{dl} \text {; white cell count } 11 \times 109 / 1\left(39 \% \text { polymorphs). Lumbar CSF-white cell count } 0.512 \times 10^{9} / 1\right. \\
(20 \% \text { polymorphs); protein } 4 \mathrm{~g} / \mathrm{dl} \text {; no culture growth. Culture of abscess contents-coliform bacillus. }\end{array}$ \\
\hline $6(1972)$ & Lumbar CSF-white cell count $2.25 \times 109 / 1$; protein $1 \mathrm{~g} / 1$; culture, $E$. coli. Culture of abscess-E. coli. \\
\hline 7 (1978) & $\begin{array}{l}\text { Haemoglobin } 14.7 \mathrm{~g} / \mathrm{dl} \text {; white cell count } 22 \times 109 / 1(55 \% \text { polymorphs }) \text {. Lumbar CSF-monocytes } \cdot 059 \times 109 / 1 \text {, } \\
\text { polymorphs } .009 \times 10^{9} / 1 \text {; protein } 1.39 \mathrm{~g} / 1 \text {; no culture growth. Culture of abscess contents-Pr. vulgaris. }\end{array}$ \\
\hline $8(1978)$ & $\begin{array}{l}\text { Lumbar CSF-white cell count } 22 \times 109 / 1 \text { (95\% polymorphs); protein } 5 \mathrm{~g} / 1 \text {; culture, Pr. vulgaris. Culture of abscess } \\
\text { contents-Pr. vulgaris. }\end{array}$ \\
\hline $9(1981)$ & $\begin{array}{l}\text { Lumbar CSF-polymorphs } 5 \cdot 75 \times 109 / 1 \text {; protein } 1.2 \mathrm{~g} / 1 \text {; culture, Serratia marcescens. Blood culture; no growth. } \\
\text { Culture of abscess contents-no growth. }\end{array}$ \\
\hline $10(1982)$ & $\begin{array}{l}\text { Lumbar CSF-polymorphs } 2 \times 10^{9} / 1 \text {; culture, Pr. vulgaris. Haemoglobin } 12.7 \mathrm{~g} / \mathrm{dl} \text {; normal blood film. } \\
\text { Culture of abscess contents-no growth. }\end{array}$ \\
\hline $11(1982)$ & $\begin{array}{l}\text { Lumbar CSF-polymorphs; culture, Pr. vulgaris. Haemoglobin } 8 \cdot 8 \mathrm{~g} / \mathrm{dl} \text {; normochromic; white cell count, normal. } \\
\text { Culture of abscess contents-Pr. vulgaris. }\end{array}$ \\
\hline $12(1982)$ & $\begin{array}{l}\text { Lumbar CSF-polymorphs } 2 \cdot 3 \times 10^{9} / 1 \text {; protein } 3 \mathrm{~g} / 1 \text {; culture, Citrobacter diversus. Culture of abscess } \\
\text { contents-Citrobacter diversus. }\end{array}$ \\
\hline
\end{tabular}

CSF $=$ cerebrospinal fluid.

Electroencephalograms (EEG) were performed in 6 patients - three of them showed epileptic activity and the remainder abnormal low voltage activity. EEG's proved inaccurate for diagnosis and localisation. The commonest sites for abscesses were the frontal and parietal lobes.

Eleven babies had cerebrospinal fluid (CSF) specimens taken (10 by lumbar puncture, and one ventricular). Eight of the specimens grew the causative organisms, which were confirmed by aspiration of the abscess. These were Escherichia coli (4 infants), Proteus vulgaris (5 infants), Staphylococcus aureus (1 infant), Citrobacter diversus (1 infant), and Serratia marcescens (1 infant) (Table $3)$. The abscess cavity was aspirated and antibiotic instilled in 9 babies. All had parenteral antibiotics, the duration varying from 3-7 weeks, and two infants subsequently had a prolonged course of oral antibiotics. Ten babies were given anticonvulsants (8 for fitting) but only three continued them for more than a year. Steroids were used twice (Table 4).

In this series mortality was $33 \%$. Three deaths occurred in infants treated before 1970 and one in 1982. At the latest follow up four of the surviving children were neurologically and developmentally normal, one was in a class for mildly retarded children and had a hemiparesis (case 5), four had hydrocephalus requiring shunting (cases $3,5,11$, and 12) and two had fits after recovery from the initial illness (cases 5 and 7). One of the recent patients (case 11) has not been followed long enough to assess his eventual neurological outcome and the other (case 12) is blind and hypertonic.

\section{Discussion}

There are more infants aged less than 6 months in the present series than in previous studies, ${ }^{1}$ most of which have not confined themselves to this age group. Several causes of cerebral abscess in infancy have been cited. In 1898, Holt ${ }^{2}$ found that trauma and otitis media were the most common predisposing factors. Other causes suggested have been skin and umbilical sepsis, ${ }^{34}$ osteomyelitis, ${ }^{3}$ and meningitis. ${ }^{4-6}$ In most series ${ }^{7}$ no predisposing causes were found in approximately $25 \%$ of the cases $(77 \%$ in the present study).

In 1973, Samson and Clark ${ }^{8}$ emphasised the importance of culturing for anaerobes in cerebral abscess pus. It is clear that both anaerobes and Gram negative organisms have replaced Staphylococcus and Streptococcus as the most common 
Table 4 Management and outcome

\begin{tabular}{|c|c|c|}
\hline Case (year) & Management & Outcome \\
\hline $1(1961)$ & $\begin{array}{l}\text { IM streptomycin, IV chloramphenicol, oral sulphadimidine, } \\
\text { IM phenobarbitone. }\end{array}$ & Death after 24 hours. \\
\hline $2(1961)$ & $\begin{array}{l}\text { IM streptomycin, IM methicillin, IM chloramphenicol, oral erythromycin, } \\
\text { oral sulphadimide (4-5 weeks). }\end{array}$ & Death 1 month after admission. \\
\hline $3(1962)$ & $\begin{array}{l}\text { IM streptomycin, chloramphenicol ( } 3 \text { wks), oral sulphadimidine ( } 2 \text { wks), } \\
\text { oral phenobarbitone ( } 5 \mathrm{wks}) \text {, oral prednisone. }\end{array}$ & Hydrocephalus. Lost to follow up. \\
\hline 4 (1969) & $\begin{array}{l}\text { IV chloramphenicol, IM kanamycin, IM ampicillin, oral sulphadimidine } \\
\text { ( } 5 \text { wks). Daily aspiration of abscess and instillation of kanamycin ( } 1 \mathrm{mth}) \text {, } \\
\text { oral phenytoin, methylphenobarbitone. }\end{array}$ & Died at 6 months of aspiration. \\
\hline $5(1972)$ & $\begin{array}{l}\text { IM gentamicin, penicillin (1 mth), oral co-trimoxazole (7 wks). Daily } \\
\text { aspiration abscess and instillation of gentamicin }(2 \mathrm{wks}), \\
\text { methylphenobarbitone. }\end{array}$ & $\begin{array}{l}\text { Age } 10 \text { yrs - hydrocephalus (VP shunt), } \\
\text { right hemiparesis, mild retardation, } \\
\text { no fits. }\end{array}$ \\
\hline $6(1972)$ & $\begin{array}{l}\text { IV chloramphenicol, aspiration abscess and instillation gentamicin into } \\
\text { ventricular reservoir }(1 \mathrm{mth}) \text {, phenobarbitone (temporarily). }\end{array}$ & Age 3 yrs-normal, no fits, lost to follow up \\
\hline 7 (1978) & $\begin{array}{l}\text { IV chloramphenicol, IM gentamicin ( } 7 \text { wks). Aspiration of abscess and } \\
\text { instillation penicillin, dexamethasone, phenytoin, phenobarbitone } \\
\text { long term. }\end{array}$ & $\begin{array}{l}\text { Age } 4 \text { yrs-normal neurologically and } \\
\text { developmentally, slight increase in } \\
\text { ventricular size, } 1 \text { fit only with fever. } \\
7 \text { mths after abscess. }\end{array}$ \\
\hline $8(1978)$ & $\begin{array}{l}\text { IV chloramphenicol, ampicillin (6 wks). Daily aspiration abscess and } \\
\text { instillation of chloramphenicol (15 dys), phenobarbitone (1 yr). }\end{array}$ & $\begin{array}{l}\text { Age } 4 \text { yrs-normal neurologically and } \\
\text { developmentally, no fits. }\end{array}$ \\
\hline $9(1981)$ & $\begin{array}{l}\text { IV chloramphenicol, gentamicin ( } 3 \text { wks), oral chloramphenicol, } \\
\text { co-trimoxazole ( } 5 \text { wks). Drainage of abscess }(\times 1) \text {, carbamazepine } \\
\text { long term. }\end{array}$ & $\begin{array}{l}\text { Age } 2 \text { yrs-normal neurologically and } \\
\text { developmentally, no fits. }\end{array}$ \\
\hline $10(1982)$ & $\begin{array}{l}\text { IV chloramphenicol ( } 2 \text { wks), IV ampicillin ( } 1 \mathrm{mth}) \text {, IV gentamicin (6 dys), } \\
\text { IV co-trimoxazole ( } 2 \text { wks). Rickham ventricular reservoir, } \\
\text { phenytoin, phenobarbitone. }\end{array}$ & $\begin{array}{l}\text { Hydrocephalus, grossly retarded, } \\
\text { died } 6 \text { wks after admission. }\end{array}$ \\
\hline $11(1982)$ & $\begin{array}{l}\text { IV chloramphenicol, ampicillin (6 wks). Aspiration of abscess }(\times 6) \text {, } \\
\text { Rickham reservoir to tap ventricles and relieve hydrocephalus. }\end{array}$ & $\begin{array}{l}\text { Hydrocephalus, VP shunt, porencephaly } \\
\text { right frontal lobe. Neurologically } \\
\text { normal at discharge. }\end{array}$ \\
\hline $12(1982)$ & $\begin{array}{l}\text { IV chloramphenicol ( } 1 \text { wk), IV gentamicin cefotaxime-(6 wks). } \\
\text { Drainage of abscess }(\times 2) \text {, Rickham reservoir to relieve hydrocephalus } \\
\text { till CSF clear, phenobarbitone, phenytoin. }\end{array}$ & $\begin{array}{l}\text { Hydrocephalus, VP shunt, hypertonic, } \\
\text { blind. }\end{array}$ \\
\hline
\end{tabular}

$\mathrm{CSF}=$ cerebrospinal fluid; $\mathrm{VP}=$ ventriculoperitoneal.

causative organisms, ${ }^{5-13}$ and in a recent report ${ }^{14}$ Candida albicans was the pathogen. The most common organisms in the present series were Gram negative. It is of interest that the pathogen in one of the recent patients was Serratia marcescens, an organism appearing more frequently in neonatal intensive care units, ${ }^{15}$ but hitherto not reported as a cause of cerebral abscess in infancy.

The most frequent presenting symptoms of cerebral abscess in infancy are vomiting, ${ }^{11}$ convulsions, ${ }^{911}$ and an enlarging head. ${ }^{7}$ In Sanford's series, ${ }^{9} 72 \%$ had ocular signs such as nystagmus, strabismus, and pupillary changes. All authors emphasise the difficulty in making an early diagnosis. In the earlier series most diagnoses were made at necropsy ( $100 \%$ of Holt's cases).

There is general agreement that parenteral penicillin and chloramphenicol are the initial antibiotics of choice to cover the most likely pathogens. ${ }^{7} 8$ Prolonged antibiotic treatment lasting 6 weeks is recommended.?
The operative management of cerebral abscess is controversial. Aspiration of the abscess cavity is considered sufficient for a total cure by some authors. ${ }^{711} 17$ Wright and Ballantine ${ }^{18}$ and Samson and Clark, ${ }^{8}$ however, found a lower mortality in those undergoing total excision of the abscess. In this series the experience with repeated aspiration was good. It is likely that unless there is a well defined abscess capsule (a rare occurrence) total excision of the abscess would destroy normal brain tissue.

Although mortality from cerebral abscess in infancy is clearly falling, morbidity is still high. From the studies with reliable follow up data ${ }^{519}$ it seems that about $60 \%$ of children may have neurological and developmental sequelae. The commonest problems reported ${ }^{1619}$ are hemiparesis, seizures, visual field defects, and learning difficulties.

Legg, Gupta, and $\operatorname{Scott}^{20}$ reviewed 70 patients who had cerebral abscess, none of whom was under 6 months old. The incidence of epilepsy in their 
follow up of 3-30 years was $72 \%$. The interval between diagnosis of cerebral abscess and onset of epilepsy was longest in the younger patients. Onset of fits was maximal 4-5 years after the abscess. Prospective studies are needed to assess the value of giving anticonvulsants for five years after a cerebral abscess.

\section{Conclusions}

The diagnosis of cerebral abscess in babies aged under 6 months remains difficult. It must be suspected in any infant with a CSF pleocytosis accompanied by an unusual organism (citrobacter, proteus, serratia) or no organism. ${ }^{4620}$ Prolonged fitting or a rapidly enlarging head are other diagnostic pointers.

To improve outcome, brain abscess should preferably be diagnosed at the stage of cerebritis. To this end, RN and CT scans and ultrasound have simplified the investigative process. ${ }^{21}$ Ultrasound is a useful tool in neonates and preferable to CT where multiple studies need to be done. It is a mobile service and enables close monitoring of the development of cerebritis, cerebral abscess, and complications such as ventriculitis. The $R N$ scan is positive in most inflammatory brain lesions, whereas CT has a lower detection rate unless a discrete abscess is present. ${ }^{22}$ If either of these scans is negative and the clinical diagnosis is cerebral abscess then the other study should be done. ${ }^{22} \mathrm{RN}$ scan and CT also show hydrocephalus which, although usually temporary, is present in a high proportion of infants with meningitis.

It is the practice at this hospital to perform ultrasound or CT, or both in all infants aged under 6 months presenting with bacterial meningitis. As a result of this policy, three patients with unsuspected cerebral abscess (cases 8,9 , and 12) were diagnosed and two (cases 4 and 11) were discovered to have multiple abscesses. Because a cerebral abscess was anticipated in the infant in case 10 , serial ultrasound studies were performed and the diagnosis was made early. Unfortunately this did not alter the outcome.

\section{References}

1 Fischer EG, McLennan JE, Suzuki Y. Cerebral abscess in children. Am J Dis Child $1981 ; 135: 746-9$.

2 Holt LE. A report of five cases of abscess of the brain in infants together with a summary of 27 collected cases in infants and very young children. Archives of Pediatrics $1898 ; 15: 81-106,161-72$.
3 Butler NR, Barrie H, Paine KWE. Cerebral abscess as a complication of neonatal sepsis. Arch Dis Child 1957;32: 461-665.

4 Smith ML, Mellor D. Proteus mirabilis meningitis and cerebral abscess in the newborn period. Arch Dis Child 1980;55:308-10.

5 Idriss ZA, Gutman LT, Knonfol NM. Brain abscess in infants and children-current status of clinical findings, management and prognosis. Clin Pediatr (Phila) 1978; 17:738-46.

6 Curless RG. Neonatal intracranial abscess: 2 cases caused by citrobacter and a literature review. Ann Neurol $1980 ; 8: 269-72$.

7 Garfield J. Brain abscesses and focal suppurative injections. In: Vinken $\mathrm{P}$, Bruyn $\mathrm{G}$, eds. Infections of the nervous system. (Handbook of clinical neurology, vol. 33, part 1). Amsterdam, New York: North Holland, 1978: $107-47$.

8 Samson DS, Clark K. A current review of brain abscess. Am J Med 1973;54:201-10.

9 Sanford H. Abscess of the brain in infants under 12 months of age. Report of 2 cases with 17 collected cases. Am J Dis Child 1928;35:256-61.

10 Salibi B. Bacteroides infection of the brain: successful management of a case with three intracranial abscesses. Arch Neur 1964;10:629-34.

11 Nestadt A, Lowry RB, Turner E. Diagnosis of brain abscess in infants and children. Lancet 1960;ii:449-53.

12 Brook I. Bacteriology of intracranial abscess in children. J Neurosurg $1981 ; 54: 484-8$.

13 Heineman HS, Braude AI. Anaerobic infection of the brain. Am J Med 1963;35:682-97.

14 Haruda F, Bergman MA, Headings D. Unrecognized candida brain abscess in infants: 2 cases and a review of the literature. Johns Hopkins Med J 1980;147:182-5.

15 Christensen GD, Korones SB, Decol L, Bulley R, McLaughlin B, Bisno AL. Epidemic Serratia marcescens in a neonatal intensive care unit: importance of the gastrointestinal tract as a reservoir. Infect Control 1982; 3:127-33.

16 Hoffman HJ, Hendrick EB, Hiscox JL. Cerebral abscesses in early infancy. $J$ Neurosurg 1970;33:172-7.

17 McGreal DA. Brain abscess in children. Can Med Assoc 1962;86:261-8.

18 Lewis Wright RL. Ballantine HT, Jr. Management of brain abscesses in children and adolescents. Am $J$ Dis Child 1967;114:113-22.

19 Carey ME, Chou SN, French LA. Long-term neurological residua in patients surviving brain abscess with surgery. $J$ Neurosurg $1971 ; 34: 652-6$.

20 Legg NJ, Gupta PC, Scott DF. Epilepsy following cerebral abscess. Brain 1973;96:259-68.

21 Crocker EF, McLaughlin AF, Morris JG, Benn R, McLeod JG, Allsop JL. Technetium brain scanning in the diagnosis and management of brain abscess. Am J Med 1974;56:192-201.

22 Masucci EF, Sauerbrunn BJ. The evolution of a brain abscess. The complementary roles of radionuclide (RN) and computed tomography (CT) scans. Clin Nucl Med $1982 ; 7: 166-70$.

Correspondence to $\mathrm{Dr}$ L Sutton, 1/33 Church Street, Balmain, New South Wales 2041, Australia.

Received 21 June 1983 